\title{
El origen de la identidad dentro de la cultura
}

\section{Paulina Ruelas}

Dice Gabriel García Márquez: "Los seres humanos no nacen para siempre el día que sus madres los alumbran: la vida los obliga a parirse a sí mismos una y otra vez, a modelarse, a transformarse, a interrogarse (a veces sin respuesta), a preguntarse para qué diablos han llegado a la tierra y qué deben hacer en ella". El tema de la identidad, el preguntarse: “iquién soy?”, “¿para que nací?”, es algo que quizá, como ha dicho Márquez, es una pregunta que la mayoría de la gente se ha hecho y a veces sin sentido. Es posible que esta pregunta se la haga uno en la juventud puesto que, en pleno desarrollo, se acumulan muchas preguntas: ¿para qué nací?, ¿qué estudiaré?, ¿en qué trabajaré?, ¿quién dice la gente que soy?, etc. Aunque muchos filósofos, escritores, psicólogos y religiosos han tratado de encontrar respuesta a la multitud de preguntas, toda pregunta lleva el mismo origen: el encontrar una identidad propia. No cabe duda que la cultura juega gran parte de esta cuestión e influye el desarrollo de la identidad personal.

En América Latina hay un concepto político de nacionalismo, en el cual se cree que la nación supera la raza. Esto se debe al discurso nacional del mestizaje que mantiene que la cultura cohesiona. Se presupone que todos los ciudadanos tienen la misma lengua, religión y cultura. En otras palabras, el nacionalismo influye y define la identidad en base a la cultura, lengua y religión. Tomemos, por ejemplo, a "los mexicanos" "colombianos" o "dominicanos": ¿qué es lo que los define como tales? Es el nacionalismo lo que nos ayuda a definirnos como tal, es nuestra cultura lo que nos ayuda a encontrarnos y podernos identificarnos como "mexicanos", "colombianos", "dominicanos", etc. Según Molano, "Aunque existen diversas definiciones (de lo que es la cultura), en general, todas coinciden en que cultura es lo que le da vida al ser humano: sus tradiciones, costumbres, fiestas, conocimiento, creencias, moral".

La tradición en América Latina ayuda a crear una identidad propia. Desde la conquista y la evangelización realizada por los españoles, América Latina adoptó la religión católica y hasta hoy es la religión en la mayoría de los países hispanoamericanos. Desde el principio, la religión, ha influido y ha hecho una identidad para cada país según sus costumbres y tradiciones, y ayudó al desarrollo de una cultura y un nacionalismo propio. La religión ha jugado un papel muy importante en la formación de la cultura.

Tomemos por ejemplo el caso de Serguei Einsenstein, que fue director de cine y teatro. Einsenstein quería hacer una película para dar a conocer a un país que no tenia identidad concreta en ese entonces. Según Grigori Alexandrove, Einsenstein decidió filmar en México pero para hacerlo tenían que conocer 
la historia y el origen de aquel país. Para esto, acudió a la ayuda e influencia de los famosos muralistas: Rivera, Orozco y Siqueiros. Einsenstein dividió la película, ¡Que viva México! en cuatro partes para dar a conocer la trayectoria del país desde su raíz indígena hasta el México actual de ese entonces. Con esto, llegó a captar el origen del país y encontró que el pasado sigue vigente y se niega a morir. Todo es un círculo que nos regresa al principio. José Vasconcelos, rector de la Universidad Nacional, con su política educativa pone la educación y las artes al servicio del estado para crear un nuevo proyecto de nación. Con los jóvenes muralistas, Vasconcelos influye en la cultura para tratar de definir el país y ese es el caso de muchos otros artistas, si no de todos, que por medio del arte tratan de explicar lo que piensan, sienten y ven por medio de su trabajo, al tiempo que intentan apoyar la formación de una identidad nacional por medio del arte.

Muchos de los escritores toman el tema de la identidad y lo relatan en sus obras y ensayos, tal como lo hizo Octavio Paz en El laberinto de la soledad (1950). En "De la Independencia a la Revolución", uno de los capítulos de ese ensayo, Paz trata de explicar "quién y qué es el mexicano". Da una explicación personal, no científica, e intenta dar una explicación histórica de la Revolución. Paz dice que el tiempo de la Revolución fue una fiesta histórica, un ritual, una catarsis y una liberación sangrienta donde los mexicanos se conocieron a sí mismos. Paz basa su ensayo en el concepto de comunión, un momento en el que se realiza una revelación de una identidad propia que define "qué es lo mexicano". La historia, que desarrolla una cultura en particular, crea una identidad propia del ser. Nuestras raíces nos llevan a encontrarnos con nosotros mismos e identificarnos como individuos pero, para esto, como dijo Paz, hay que volver al origen, a nuestra historia, a nuestra tierra, a nuestra cultura.

La literatura, que también es parte de la cultura, habla sobre este origen de la identidad e influye en nuestro concepto del ser. Este concepto se puede ver no sólo en Paz sino en muchos otros escritores que sólo con su técnica o forma de escribir, dan a conocer este "regreso al origen". Carlos Fuentes y Juan Rulfo, por ejemplo, escriben de una forma con una estructura fragmentada, polifónica, elíptica y con un lenguaje poético. Tomemos como ejemplo la novela Pedro Paramo de Juan Rulfo. Esta obra es un relato sobre el origen: la novela habla sobre la memoria de la nostalgia que, por consecuencia, nos lleva a nuestro origen. E1 acto de recordar hace presente el pasado. La nostalgia es dolor del origen, de un recuerdo, de una memoria. El tema de la nostalgia es muy importante en el sentido que todos los personajes en esta novela tienen nostalgia: dolor por su origen. Pedro Páramo por ejemplo, tiene nostalgia de Susana y desea regresar al pasado porque está enamorado de una mujer que conoció en su infancia y que no le corresponde. Regresar al pasado es regresar al tiempo feliz. También podemos tomar el ejemplo de Juan Preciado que carece de la figura paterna, por eso regresa a su origen en búsqueda de su padre. En la novela, llegar al final es llegar al principio: el recuerdo y la memoria son el regreso al origen y llegar al origen significa poner orden y, en consecuencia, identificar y saber quiénes somos y de dónde venimos.

Tras el transcurso del tiempo vemos una evolución y con esto vemos el desarrollo de cada país, su cultura y religión, ya sea en la literatura, el cine o el arte en general. No cabe duda que todo es un proceso y todo toma tiempo para sentirnos identificados, pues toma tiempo el encontrarse así mismo e identificarse con 
algo y/o alguien. Según Marcela Lagarde:

La identidad siempre está en proceso constructivo, no es estática ni coherente, no se corresponde mecánicamente con los estereotipos. Cada persona reacciona de manera creativa al resolver su vida y, al resolverla, elabora los contenidos asignados a partir de su experiencia, sus anhelos y sus deseos sobre sí misma [...] los cambios de identidad son una constante a lo largo de la vida. Sus transformaciones cualitativas ocurren en procesos de crisis. Por ello, la identidad se define por semejanza o diferencia en cuanto a los referentes simbólicos y ejemplares. Cada quien es semejante y diferente. (20)

Tal vez uno nunca podrá encontrar una identidad concreta, y eso no siempre es malo; pues tal como cada cultura se va desarrollando, evolucionando, creciendo y modernizando, uno también lo hace, a veces sin darnos cuenta que lo hacemos. Nuestro ser, nuestra identidad, nos hace únicos y tendremos que, como ha dicho Márquez, darnos a conocer y enfrentar la vida. Muchas veces uno aprende por medio de la historia, pues ésta nos da una sabiduría de la vida, un descernimiento, una experiencia particular, una identidad propia. 


\section{Bibliografía}

"La Identidad". Guía para la promoción personal de las mujeres gitanas. Fundación Secretariado Gitano, s.f. Web. 20 Abril 2015.

Molano, Olga Lucía. "Identidad cultural, un concepto que evoluciona”. Ópera 7 (2007): 69-84. Redalyc. Web. 20 Abril 2015. 